\title{
Content and Results of Program Forming Internality as a Factor of Future Psychologists' Readiness for Personal and Professional Self-Development
}

\section{Зміст і результати впровадження програми формування інтернальності як чинника готовності майбутніх психологів до особистісно-професійного саморозвитку}

\section{Tetiana Ketler-Mytnytska}

Senior lecturer, Department of Natural Sciences, Municipal Institution of Higher Education «Khortytsia National Educational and Rehabilitation Academy» of Zaporizhzhia Regional Council, Zaporizhzhia (Ukraine)

ORCID ID: https://orcid.org/0000-0002-1665-4282

E-mail: catmeatt@gmail.com

\section{Тетяна Кетлер-Митницька}

Старший викладач кафедри природничо-наукових дисциплін, комунальний заклад вищої освіти «Хортицька національна навчально-реабілітаційна академія» Запорізької обласної ради, м. Запоріжжя (Україна)

\section{ABSTRACT}

The purpose of the article is to describe the content and to analyze the results of the implementation of the program forming internality as a factor of the future psychologists' readiness for personal and professional self-development. Urgency of the problem of forming future psychologists' internality is considered

Address for correspondence, e-mail: kpnu_lab_ps@ukr.net Copyright: (c) Ketler-Mytnytska Tetiana

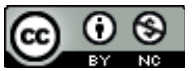

The article is licensed under CC BY-NC 4.0 International

(https://creativecommons.org/licenses/by-nc/4.0/)

(C) Ketler-Mytnytska Tetiana

DOI (article): https://doi.org/10.32626/2227-6246.2019-46.199-218 
DOI: https://doi.org/10.32626/2227-6246.2019-46 2019. Випуск 46

in the context of professional requirements. The data of experimental research concerning the forming of future psychologists' internality and readiness for personal and professional self-development are presented. It was found that the researches didn't reveal the nature of the relationship between these traits, and didn't content the means of internality forming intended for stimulation the ability to self-development.

The article presents the author's model describing the system of formation of internality as a factor of future psychologists' readiness for personal and professional self-development. The model provides the introduction of internality forming program that includes educational activities, psychological training and discussion club meetings. The article reveals the content, forms and methods of proposed directions of work. The purpose of the program is to develop the cognitive, personal and regulatory components of future psychologists' internality. In its turn, their formation should stimulate cognitive, axiological and motivational, behavioral components of readiness for personal and professional self-development. Information about the educational institutions and the number of future psychologists of fourth-and fifth-years who participated in the forming experiment is provided. Psychodiagnostic techniques used for comparison of each component's level of formation before and after the experiment are presented.

Factor analysis established the factors of future psychologists' internality in the context of its influence on the readiness for personal and professional selfdevelopment. The levels of development of each factor were compared before and after the program implementation. The analysis confirmed the statistically significant positive dynamics of development of appointed factors.

The results of a forming experiment allow us to claim that the author's program of the internality development is effective. Therefore, its introduction into the higher education practice will help to stimulate the personal and professional self-development of future psychologists.

Key words: internality; readiness for personal and professional selfdevelopment; model of internality developing; forming experiment; factors.

\section{Вступ}

У контексті професійного становлення майбутніх психологів, вимог до особистісних характеристик спеціалістів цього профілю все більше уваги приділяється проблемі забезпечення готовності студентів до цілеспрямованого особис(C) Ketler-Mytnytska Tetiana

DOI (article): https://doi.org/10.32626/2227-6246.2019-46.199-218 http://journals.uran.ua/index.php/2227-6246 
DOI: https://doi.org/10.32626/2227-6246.2019-46

тісно-професійного саморозвитку, вдосконалення власних якостей і вмінь згідно з вимогами обраного фаху. Одним із важливих внутрішніх чинників такої готовності є інтернальність, яку традиційно пов'язують із відповідальністю за результати своєї навчально-професійної діяльності, визнанням авторства своїх перемог і поразок на шляху до професійного успіху.

Поняття «інтернальність» використовується для позначення одного з двох полюсів локусу контролю - біполярного концепту, запровадженого американським психологом Дж. Роттером. Дослідник звернув увагу на те, якими чинниками люди пояснюють свої успіхи й невдачі, на підставі чого виокремив два типи локалізації контролю: інтернальний (від англ. internal - внутрішній) та екстернальний (від англ. external - зовнішній). Інтернали пов'язують позитивні та негативні події життя з наслідками власних вчинків, а екстернали перекладають відповідальність на випадок, долю чи значущих осіб (Rotter, 1966). У межах розробленої Дж. Роттером теорії соціального научіння під інтернальністю розуміється генералізоване очікування успіху як результату власних зусиль, а не збігу обставин чи сторонньої допомоги. Таке узагальнення формується внаслідок аналізу людиною минулого досвіду, згідно з яким активна, самостійна поведінка здебільшого отримує позитивне підкріплення, тобто призводить до успіху (Rotter, 1982).

Під готовністю до особистісно-професійного саморозвитку більшість науковців розуміє комплекс особистісних властивостей, які забезпечують ефективність самовдосконалення професійно важливих якостей та умінь, зокрема: рефлексію, проектування і реалізацію прогресивних перетворень власної особистості, саморегуляцію навчально-професійної діяльності (Фрицюк, 2016: 380); здатність до підвищення рівня власної професійної компетентності (Поплавська, 2014: 7) тощо.

Актуальність дослідження зумовлено високою значущістю інтернальності й готовності до особистісно-професійного (C) Ketler-Mytnytska Tetiana DOI (article): https://doi.org/10.32626/2227-6246.2019-46.199-218 
саморозвитку в контексті вимог майбутньої професійної діяльності студентів-психологів. Згідно з положеннями етичного кодексу психолога, прийнятого на першому установчому з'їзді Товариства психологів України 20.12.1990р. у м. Києві, психологи несуть особисту відповідальність за свою роботу (п. 1.1), забезпечують кваліфіковане виконання різних напрямів професійної діяльності (п. 3.3), повинні якомога швидше коригувати та розв'язувати власні особистісні проблеми, що негативно впливають на якість виконання обов'язків (п. 2.4) (Психолог, 2004). Відповідно до Стандарту вищої освіти України з галузі знань 05 «Соціальні та поведінкові науки», спеціальності 053 «Психологія», для першого (бакалаврського) рівня освіти, затвердженого та введеного в дію наказом Міністерства освіти і науки України № 565 від 24.04.2019 р., майбутні психологи мають володіти такими здатностями (компетентностями): ПР17 демонструвати соціально відповідальну та свідому поведінку; AB1 брати відповідальність за прийняття рішень у непередбачуваних умовах; ПР11 забезпечувати ефективність власних дій; CК12 здатністю до особистісного і професійного самовдосконалення, навчання та саморозвитку; ПР15 умінням відповідально ставитися до професійного самовдосконалення, навчання та саморозвитку (Стандарт вищої освіти України 3 галузі знань 05 «Соціальні та поведінкові науки», спеціальності 053 «Психологія», 2019: 6-12).

У зв'язку з високою значущістю зазначених властивостей доцільними є оцінка та підвищення їх розвиненості. Аналіз сучасних досліджень довів, що експериментально-дослідна робота, спрямована на формування інтернальності майбутніх психологів, здійснювалася такими науковцями:

- Н. Фалько, яка розробила програму психологічного супроводу студентів закладів вищої освіти психолого-педагогічного спрямування з метою формування їх інтернальних якостей; упровадження тренінгової програми, зумовлене недостатніми показниками інтернальності майбутніх соціаль(C) Ketler-Mytnytska Tetiana

DOI (article): https://doi.org/10.32626/2227-6246.2019-46.199-218 
них педагогів і психологів, довело ефективність використання психологічного тренінгу, самозвітів, індивідуального консультування та навчального процесу для підвищення рівнів інтернальності й інтернальних якостей студентів (Фалько, 2009: 313-322);

- В. Мараловим під час упровадження програми щодо формування позитивного ставлення студентів до навчальнопрофесійної діяльності (Маралов, 2011: 140);

- О. Міненко у контексті формування професійно значущих новоутворень студентів-психологів в умовах інтенсивного навчання (Міненко, 2004: 15);

- А. Чурсіною при впровадженні педагогічних умов формування готовності студентів закладу вищої освіти до професійного саморозвитку (Чурсіна, 2011: 108-136).

О. Затворнюк запропонувала алгоритм складання програми особистісно-професійного саморозвитку майбутніх психологів, який охопив основні етапи цього процесу: мотивування себе наближенням до ідеалу «Я»; визначення системи цілей у часовій перспективі та складання їх ієрархії; аналіз наявних ресурсів і можливих перешкод; складання плану дій, визначення їх методів і прийомів (Затворнюк, 2016: 293-296).

Отже, інтернальність і готовність майбутніх психологів вивчалися як окремі характеристики студентів. У дослідженнях не висвітлено характер зв'язку між зазначеними властивостями, не було виявлено й розроблених засобів формування інтернальності з метою стимулювання здатності до саморозвитку в особистісно-професійній сфері. У зв'язку з цим нами розроблено програму формування інтернальності майбутніх психологів як чинника готовності до особистісно-професійного саморозвитку.

Мета статті - описати зміст і проаналізувати результати впровадження програми формування інтернальності як чинника готовності майбутніх психологів до особистісно-професійного саморозвитку.

(C) Ketler-Mytnytska Tetiana

DOI (article): https://doi.org/10.32626/2227-6246.2019-46.199-218 


\section{Завдання статті}

1. Обгрунтувати актуальність формування інтернальності як чинника готовності до особистісно-професійного саморозвитку майбутніх психологів у контексті вимог професійної діяльності.

2. Проаналізувати досвід експериментально-дослідної роботи щодо формування інтернальності майбутніх психологів і їх готовності до саморозвитку в особистісній і професійній сферах.

3. Описати зміст авторської програми формування інтернальності як чинника готовності майбутніх психологів до особистісно-професійного саморозвитку.

4. Проілюструвати ефективність розробленої програми.

\section{Методи та методики дослідження}

В основу експериментально-дослідної роботи покладено авторську модель системи формування інтернальності як чинника готовності майбутніх психологів до особистіснопрофесійного саморозвитку. Модель передбачає впровадження програми формування інтернальності, яка включає тренінгові та навчальні заняття, а також - залучення студентів до засідань дискусійного клубу з проблематики інтернальності та самовдосконалення. Форми та методи кожного напрямку діяльності обрані за критерієм ефективності, доведеної іншими дослідниками. Реалізація програми передбачає формування трьох компонентів інтернальності: когнітивного (інтернальні атрибуції), особистісного (інтернальні якості) та регуляторного (інтернальна поведінка). Механізмами, що відповідають зазначеним компонентам, є внутрішня локалізація: атрибуцій, відповідальності та контролю. Своєю чергою, компоненти та механізми інтернальності впливають на компоненти готовності майбутніх психологів до особистіснопрофесійного саморозвитку завдяки: забезпеченню внутрішніх умов особистісно-професійного саморозвитку, складанню та реалізації його програми (рис. 1).

(C) Ketler-Mytnytska Tetiana

DOI (article): https://doi.org/10.32626/2227-6246.2019-46.199-218 


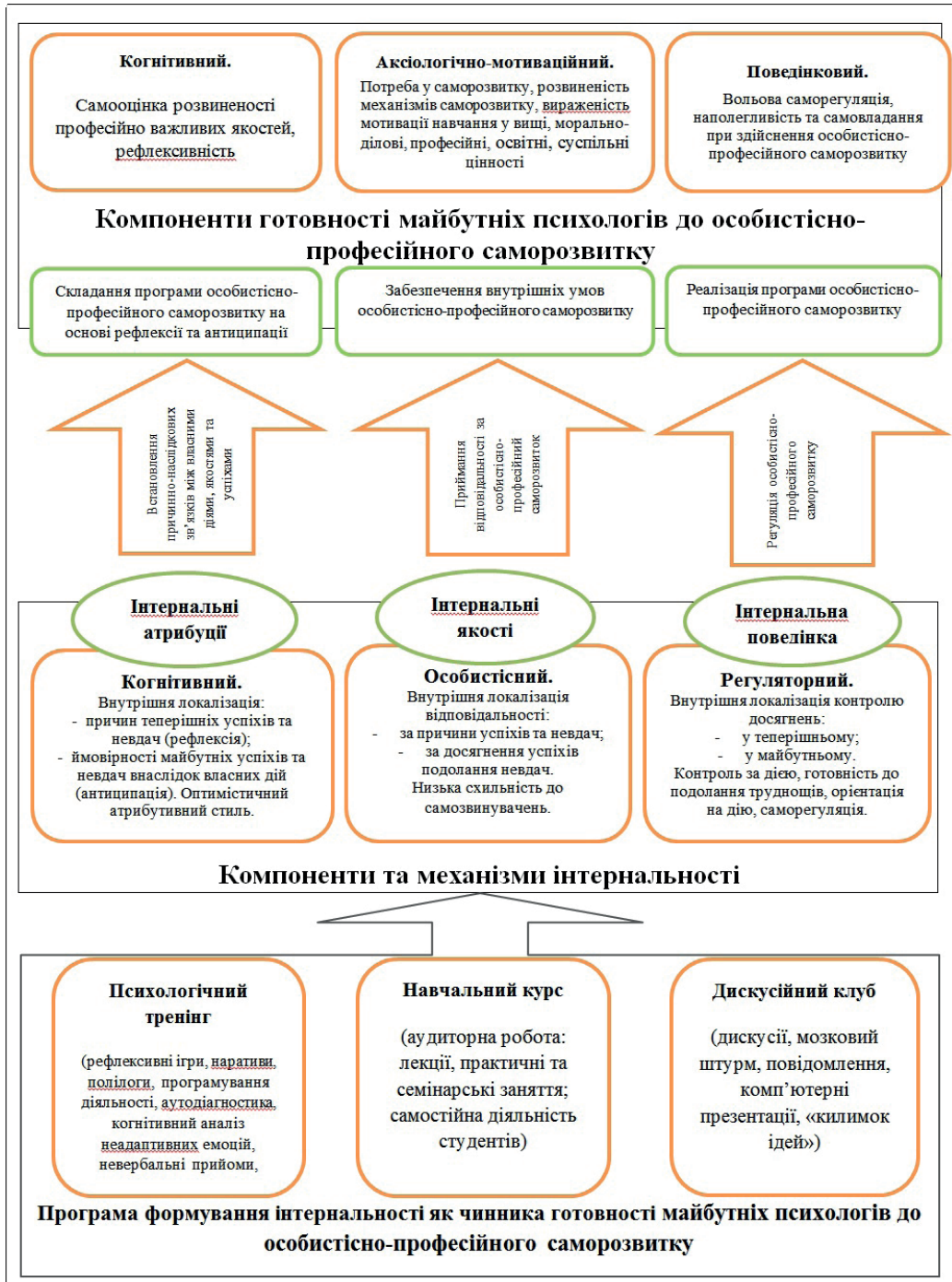

Puc. 1. Модель системи формування інтернальності як чинника готовності майбутніх психологів до особистісно-професійного саморозвитку

(C) Ketler-Mytnytska Tetiana

DOI (article): https://doi.org/10.32626/2227-6246.2019-46.199-218 
Програма формування інтернальності включає: психологічний тренінг; навчальний курс «Теоретико-методичні основи формування інтернальності майбутніх психологів»; дискусійний клуб «Self-made man: практика інтернальності» .

Формувальний експеримент проведено упродовж 20172018 рр. на базі Класичного приватного університету (м. Запоріжжя), Львівського національного університету ім. Івана Франка, Національного університету «Києво-Могилянська академія». У формувальному етапі взяли участь студенти 4-го та 5-го курсів (по 64 студенти експериментальної та контрольної груп). У зв'язку з неефективністю роботи з великою кількістю осіб членів експериментальної групи поділено на дві підгрупи по 32 особи, які займалися за однаковою програмою у різні дні тижня.

Основною формою впливу обрано психологічний тренінг, мета якого полягала у підвищенні сформованості компонентів інтернальності майбутніх психологів як чинника їх готовності до особистісно-професійного саморозвитку. Програма тренінгу передбачала проведення 17 занять тривалістю 3 академічних години кожне упродовж першого півріччя (17 тижнів). Реалізація програми психологічного тренінгу розрахована на п'ять етапів: настановний; формування когнітивного, особистісного та регуляторного компонентів інтернальності майбутніх психологів; завершальний етап. У програмі використано такі форми роботи, як: рефлексивні ігри, рефлексивні контрасти, вправи-інтроспекції, наративи, метафоричні історії, вправи-візуалізації, дискусії, полілоги, програмування діяльності, когнітивний аналіз неадаптивних емоцій, елементи психомалюнка, невербальні прийоми, психогімнастику, елементи тайм-менеджменту, інсценування, рольові ігри, дихальні вправи тощо. Змістовно завдання тренінгу представлено заняттями «Рефлексія крізь призму інтернальності», «Я - психолог: на шляху до професійного ідеалу», «Інтернальні якості майбутніх психологів», «Труднощі (C) Ketler-Mytnytska Tetiana

DOI (article): https://doi.org/10.32626/2227-6246.2019-46.199-218 
навчально-професійної діяльності та їх подолання» тощо. До тренінгу включено міні-лекції «Інтернальність та її значення для діяльності психолога», «Компоненти інтернальності», «Поняття особистісно-професійного саморозвитку». Реалізації мети та завдань тренінгу сприяла система письмових (твір-самоаналіз, сценарій мультфільму, міні-казка) й усних (підготовка до інсценування, практичне застосування конкретного прийому саморозвитку, міні-експеримент тощо) домашніх завдань.

Другим напрямком програми формування було викладання навчального курсу «Теоретико-летодичні основи формування інтернальності майбутніх психологів» загальним обсягом 90 н. г., із яких 56 н. г. - самостійної діяльності, 34 н. г. - аудиторної роботи (14 н. г. лекцій, 8 н. г. семінарських занять, 12 н. г. практичних занять). Метою навчального курсу $є$ теоретичне обгрунтування та методичне забезпечення формування інтернальності майбутніх психологів як чинника їх особистісно-професійного саморозвитку. Зміст програми курсу розподілено на шість тем і два змістовні модулі: «Теоретичні основи формування інтернальності як чинника особистісно-професійного саморозвитку майбутніх психологів» і «Методика формування компонентів інтернальності» .

Третім напрямком діяльності, передбаченим програмою, була організація засідань дискусійного клубу «Self-made man: практика інтернальності», мета якого полягала у формуванні інтернальності майбутніх психологів і підвищенні мотивації особистісно-професійного саморозвитку на основі обговорення сценаріїв життєвого успіху self-made особистостей. Програма дискусійного клубу передбачала проведення 10 занять у три етапи: підготовчий, основний і завершальний.

До впровадження програми проведено констатувальний експеримент. Психодіагностичний інструментарій дослідження розподілено на два блоки. Перший блок охопив методики, за допомогою яких визначалася сформованість компонентів (C) Ketler-Mytnytska Tetiana DOI (article): https://doi.org/10.32626/2227-6246.2019-46.199-218 
готовності майбутніх психологів до особистісно-професійного саморозвитку:

- для встановлення сформованості когнітивного колпонента: тест оцінки особистісних якостей «Психологічний особистісний профіль» (Т. Ратанова, Н. Шляхта); методика визначення рівня рефлексивності А. Карпова, В. Понамарьової;

- для встановлення сформованості аксіологічно-лотиваційного колпонента: опитувальник «Диспозиційна характеристика саморозвитку особистості» С. Кузікової; опитувальник «Мотивація навчання у виші» Т. Ільїної; методика «Морфологічний тест життєвих цінностей» В. Сопова, Л. Карпушиної;

- для встановлення сформованості поведінкового колпонента: методика «Дослідження вольової саморегуляції» А. Зверькова й Е. Ейдмана.

Другий блок містив методики, спрямовані на дослідження сформованості компонентів інтернальності майбутніх психологів:

- для встановлення сформованості когнітивного колпонента: опитувальник «Локалізація контролю» (за О. Ксенофонтовою) - 5 шкал; тест «Самооцінка рівня онтогенетичної рефлексії» (за М. Фетискіним, В. Козловим, Г. Мануйловим); тест «Здатність до прогнозування» Л. Регуш; тест атрибутивних стилів (ТАС) Л. Рудіної;

- для встановлення сформованості особистісного колпонента: опитувальник «Локус контролю» (за О. Ксенофонтовою) - 7 шкал;

- для встановлення сформованості регуляторного колпонента: опитувальник «Шкала контролю за дією (Ю. Куль в адаптації С. Шапкіна); опитувальник «Локус контролю» (за О. Ксенофонтовою) - 3 шкали; опитувальник «Стиль саморегуляції поведінки - ССП-98» (В. Моросанова).

За допомогою факторного аналізу після впровадження програми формування інтернальності як чинника готовності (c) Ketler-Mytnytska Tetiana

DOI (article): https://doi.org/10.32626/2227-6246.2019-46.199-218 http://journals.uran.ua/index.php/2227-6246 
майбутніх психологів до особистісно-професійного саморозвитку ми виявили динаміку рівня розвитку кожного фактора й за допомогою t-критерію Стьюдента порівняли його значення до та після експериментального впливу.

У результаті дослідження рівнів розвитку фактора «Інтернальність у сфері досягнень» виявлено, що після проведеної розвивальної роботи в учасників експериментальної групи зросла кількість осіб із середнім (із $45 \%$ до 52\%) і високим (iз $24 \%$ до $32 \%$ ) рівнями цього фактора та зменшилась - із низьким (із 8\% до 4\%) ( $\mathrm{t}=1,342$ при $\mathrm{p} \leq 0,05)$. Дослідження також засвідчило значущу різницю між рівнями розвитку цього фактора в експериментальній і контрольній групах. Отже, у майбутніх психологів експериментальної групи, порівняно з учасниками контрольної групи, зріс рівень інтернальності у сфері досягнень. У студентів контрольної групи рівні розвитку цього фактора статистично значуще не змінилися. Порівняння показників фактора в учасників експериментальної групи до та після реалізації програми виявило, що серед них зросла кількість тих, хто має високий рівень розвитку (з 16\% до $35 \%$ ) за рахунок зменшення кількості осіб із низьким (із $36 \%$ до $26 \%$ ) і середнім (із $51 \%$ до $48 \%$ ) рівнями. Такі зміни є статистично значущими $(\mathrm{t}=2,245$ при $\mathrm{p} \leq 0,05)$. У контрольній групі також зросла кількість осіб із високим рівнем розвитку цього фактора (з 10\% до 17\%) за рахунок зменшення кількості осіб із низьким його рівнем (із $8 \%$ до 6\%); ці результати є статистично значущими.

Аналіз результатів повторної діагностики фактора «Потреба у саморозвитку" в майбутніх психологів, які утворили експериментальну групу, дав підстави зробити висновки, що серед них зменшилася кількість осіб із низьким рівнем його розвитку (з 27\% до 20\%) і зросла із середнім (із $48 \%$ до $50 \%$ ) і високим (із 29\% до $32 \%$ ) рівнями; ці зміни є статистично значущими ( $\mathrm{t}=2,236$ при $\mathrm{p} \geq 0,05)$. В учасників контрольної групи також зросла кількість осіб із високим рівнем розвитку цього фактора (з $21 \%$ до $24 \%$ ) за рахунок (C) Ketler-Mytnytska Tetiana

DOI (article): https://doi.org/10.32626/2227-6246.2019-46.199-218 
зменшення кількості осіб із низьким його рівнем (із $27 \%$ до $20 \%$ ); ці результати є статистично значущими.

Вивчення динаміки змін рівнів фактора «Мотивація оволодіння професією у майбутніх психологів» свідчить, що серед них зменшилася кількість осіб із низьким рівнем його розвитку (з 29\% до 14\%), зросла - із середнім (із $40 \%$ до $48 \%$ ) і високим (із $31 \%$ до $38 \%$ ) рівнями; ці зміни є статистично значущими ( $\mathrm{t}=0,253$ при $\mathrm{p} \geq 0,05)$. В учасників контрольної групи також зросла кількість осіб із високим рівнем розвитку фактора «Мотивація оволодіння професією у майбутніх психологів» (з 26\% до 28\%) за рахунок зменшення кількості осіб із низьким його рівнем (із $31 \%$ до $25 \%$ ); ці результати також є статистично значущими.

Аналіз результатів повторної діагностики фактора «Розгляд майбутньої професійної діяльності» у майбутніх психологів, які утворили експериментальну групу, дав підстави зробити висновки, що, хоча серед них зменшилася кількість осіб із низьким рівнем його розвитку (з $24 \%$ до $16 \%$ ) і зросла - із середнім (із $42 \%$ до $47 \%$ ) і високим (із $34 \%$ до $37 \%$ ) рівнями, однак такі зміни не є значущими ( $\mathrm{t}=-0,342$ при $\mathrm{p} \geq 0,05)$. В учасників контрольної групи також зменшилася кількість осіб із низьким рівнем його розвитку (з $22 \%$ до $16 \%$ ) і зросла із середнім (із $52 \%$ до $53 \%$ ) і високим (із $26 \%$ до $28 \%$ ) рівнями; ці результати є статистично значущими.

Динаміку показників рівнів факторного навантаження компонентів інтернальності у членів експериментальної та контрольної груп до та після експерименту представлено у табл. 1.

Отже, майбутні психологи, які взяли участь у заняттях за розробленою програмою, мають вищий рівень розвитку інтернальності та готовності до особистісно-професійного саморозвитку, ніж ті, з якими такі заняття не проводилися. 
Динаміка показників рівнів факторного навантаження складових компонентів інтернальності як чинника готовності майбутніх психологів до особистіснопрофесійного саморозвитку $(\mathrm{n}=64)$

\begin{tabular}{|c|c|c|c|c|c|c|c|c|c|c|c|c|c|c|}
\hline \multirow{3}{*}{ Фактор } & & \multicolumn{6}{|c|}{ До експерименту } & \multicolumn{6}{|c|}{$\begin{array}{c}\text { Після } \\
\text { експерименту }\end{array}$} & \multirow{3}{*}{$\begin{array}{l}\text { t-кри- } \\
\text { терій }\end{array}$} \\
\hline & & \multicolumn{2}{|c|}{$\mathbf{H}$} & \multicolumn{2}{|c|}{$\mathrm{C}$} & \multicolumn{2}{|c|}{ B } & \multicolumn{2}{|c|}{$\mathbf{H}$} & \multicolumn{2}{|c|}{ C } & \multicolumn{2}{|c|}{ B } & \\
\hline & & $\mathbf{N}$ & $\%$ & $\mathbf{N}$ & $\%$ & $\mathbf{N}$ & $\%$ & $\mathbf{N}$ & $\%$ & $\mathbf{N}$ & $\%$ & $\mathbf{N}$ & $\%$ & \\
\hline \multirow{2}{*}{$\begin{array}{l}\text { Інтерналь- } \\
\text { ність у сфері } \\
\text { досягнень } \\
\end{array}$} & $\mathrm{E} \Gamma$ & 9 & 33 & 18 & 46 & 9 & 28 & 4 & 34 & 19 & 54 & 11 & 33 & \multirow{2}{*}{1,342} \\
\hline & $\kappa \Gamma$ & 8 & 27 & 15 & 48 & 10 & 25 & 5 & 25 & 21 & 44 & 6 & 31 & \\
\hline \multirow{2}{*}{$\begin{array}{l}\text { Особистісні } \\
\text { властивості }\end{array}$} & $\mathrm{E} \Gamma$ & 7 & 33 & 18 & 51 & 6 & 16 & 4 & 17 & 19 & 48 & 9 & 35 & \multirow{2}{*}{2,245} \\
\hline & Кг & 8 & 36 & 17 & 54 & 7 & 10 & 6 & 26 & 14 & 57 & 12 & 17 & \\
\hline \multirow{2}{*}{\begin{tabular}{|l|} 
Потреба у са- \\
морозвитку
\end{tabular}} & $\mathrm{E} \Gamma$ & 8 & 24 & 14 & 46 & 7 & 28 & 4 & 19 & 17 & 49 & 12 & 31 & \multirow{2}{*}{2,236} \\
\hline & Кг & 11 & 27 & 16 & 52 & 6 & 21 & 8 & 20 & 14 & 56 & 10 & 24 & \\
\hline \multirow{2}{*}{$\begin{array}{l}\text { Мотивація } \\
\text { оволодіння } \\
\text { професією }\end{array}$} & $\mathrm{E} \Gamma$ & 7 & 30 & 17 & 39 & 7 & 28 & 4 & 13 & 19 & 49 & 11 & 38 & \multirow{2}{*}{0,253} \\
\hline & $\kappa \Gamma$ & 8 & 31 & 20 & 44 & 4 & 25 & 5 & 25 & 19 & 46 & 8 & 29 & \\
\hline \multirow{2}{*}{$\begin{array}{l}\text { Розгляд } \\
\text { майбутньої } \\
\text { діяльності }\end{array}$} & $\mathrm{E} \Gamma$ & 8 & 26 & 14 & 41 & 11 & 33 & 6 & 17 & 13 & 48 & 14 & 36 & \multirow{2}{*}{$-0,342$} \\
\hline & Кг & 6 & 22 & 17 & 52 & 9 & 26 & 4 & 19 & 16 & 53 & 12 & 28 & \\
\hline
\end{tabular}

Примітка: * $\mathrm{p}<0,05$.

\section{Результати та дискусії}

Згідно з результатами емпіричного дослідження, після впровадження програми майбутні психологи експериментальної групи стали самостійнішими, здатними досягати успіхів у майбутній професійній діяльності, приймати самостійні рішення та брати на себе відповідальність за власні вчинки, позитивні й негативні результати спілкування. Вони об'єктивніше сприймають себе та власний вплив на успіхи i невдачі, спрямовані на саморозвиток у професійній діяльності, бажають оволодіти обраною професією.

(C) Ketler-Mytnytska Tetiana

DOI (article): https://doi.org/10.32626/2227-6246.2019-46.199-218 
Отримані статистичні дані щодо взаємозв'язку рівня інтернальності й орієнтованості на саморозвиток узгоджуються з даними Дж. Зававі та С. Хемейдех, які встановили, що інтернальність негативно корелює з депресивністю та позитивно - із задоволеністю життям. Своєю чергою, задоволеність життям сприяє схильності до самовдосконалення, оскільки щасливі люди більше зацікавлені у досягненнях, частіше ставлять перед собою навчальні цілі та працюють над собою заради їх досягнення (Zawawi \& Hamaideh, 2009: 92).

Дані щодо ефективності застосування тренінгової роботи для стимулювання готовності до саморозвитку й інтернальності майбутніх психологів підтверджують результати експерименту Л. Терещенко. Дослідниця використовувала тренінг із метою забезпечення усвідомлення рівної міри власної відповідальності й відповідальності партнера у виникненні та вирішенні різних ситуацій спілкування, забезпечення корекції студентами своїх несприятливих станів у спілкуванні, розвитку навичок суб'єкт-суб'єктної взаємодії (Терещенко, 2017: 220).

Висновок про ефективність поєднання тренінгової роботи з навчальними заняттями підтверджується результатами експериментально-дослідної роботи Н. Чорної, яка успішно запровадила спеціально розроблені педагогічні умови формування готовності студентів до професійного саморозвитку, стимулювання почуття відповідальності за власні дії (Чорна, 2016: 99-117).

Експериментальних даних щодо застосування дискусійного клубу з метою розвитку інтернальності та готовності до особистісно-професійного саморозвитку не виявлено. Отже, ефективність застосування такої форми роботи з майбутніми психологами засвідчено цим дослідженням.

\section{Висновки}

Отримані результати формувального експерименту дають підстави стверджувати, що авторська програма розвитку (c) Ketler-Mytnytska Tetiana

DOI (article): https://doi.org/10.32626/2227-6246.2019-46.199-218 
інтернальності як чинника готовності майбутніх психологів до особистісно-професійного саморозвитку є ефективною, а iї впровадження у роботу закладів вищої освіти сприятиме стимулюванню особистісно-професійного саморозвитку майбутніх психологів. Перспективи подальших розвідок убачаємо в установленні наявності або відсутності впливу зазначених показників на рівень навчальної успішності студентів.

\section{Література}

Етичний кодекс психолога. Психолог. 2004. № 43 (139). С. 1-4 (вкладка). Затворнюк О. М. Формування у майбутніх психологів готовності до професійного самовдосконалення: дис. ... канд. пед. наук: 13.00 .04 . Київ : Нац. пед. ун-т ім. М. П. Драгоманова, 2016. 310 с.

Маралов В. Г., Воронина О. А., Кисилева Е. П. Студент как субъект саморазвития и отношения к учебно-профессиональной деятельности / под ред. В. Г. Маралова. Москва : Академический проект; Мир, 2011. 190 с.

Міненко О. О. Особистісне змінювання в процесі професійної підготовки студентів-психологів: автореф. дис. ... канд. психол. наук: 19.00.07. Київ : Нац. пед. ун-т ім. М. П. Драгоманова, 2004. 20 с.

Поплавська М. В. Формування готовності майбутніх інженерів до професійно-особистісного саморозвитку: автореф. дис. ... канд. пед. наук: 13.00.04. Харків : Укр. інж.-пед. акад., 2014. 20 с.

Стандарт вищої освіти України з галузі знань 05 «Соціальні та поведінкові науки», спеціальності 053 «Психологія», для першого (бакалаврського) рівня освіти. Видання офіційне. Київ : Міністерство освіти і науки України, 2019. 15 с.

Терещенко Л. А. Формування прагнення до саморозвитку у студентівпсихологів як фактора запобігання невротичних розладів їхньої особистості. Діяльнісна самореалізація особистості в освітньолу nросторі: монографія / колектив авторів: В. В. Бучма, О. В. Гурова, Л. В. Дзюбко та ін.; за ред. С. Д. Максименка. Київ : Видавничий дім «Слово», 2017. С. 208-224.

Фалько Н. М. Психологічний супровід студентів ВНЗ психолого-педагогічних спеціальностей з метою формування їх інтернальних якостей. Збірник наукових пращь Кам'янеиь-Подільського національного університету імені Івана Огієнка, Інституту психологї̈ ім. Г. С. Костюка АПН України / за ред. С. Д. Максименка, Л. А. Онуфрієвої. Кам'янець-Подільський : Аксіома, 2009. Вип. 6. Ч. 2. C. $312-323$.

(C) Ketler-Mytnytska Tetiana

DOI (article): https://doi.org/10.32626/2227-6246.2019-46.199-218 
Фрицюк В. А. Сутнісні характеристики готовності майбутніх фахівців до професійного саморозвитку. Проблеми інженерно-педагогічної освіти. 2016. № 50-51. С. 374-384.

Чорна Н. Б. Формування готовності до професійного саморозвитку майбутніх учителів мистецьких спеціальностей: дис. ... канд. пед. наук: 13.00.04. Вінниця : Вінницький держ. пед. ун-т імені Михайла Коцюбинського, 2016. 259 с.

Чурсина А. С. Формирование готовности к профессиональному саморазвитию у студентов вуза в процессе изучения психолого-педагогических дисциплин: дис. ... канд. пед. наук: 13.00.08. Челябинск : Челябинский гос. ун-т, 2011. 162 с.

Rotter, J. B. (1966). Generalized expectances for internal versus external control of reinforcement. Psychol. Monogr., 80, 1, 11-28.

Rotter, J. B. (1982). The development and applications of social learning theory: Selected papers. New York : Praeger. 367 p.

Zawawi, J. A., \& Hamaideh, S. H. (2009). Depressive Symptoms and Their Correlates with Locus of Control and Satisfaction with Life among Jordanian College Students. Europe's Journal of Psychology, 4, 71-103.

\section{References}

Etychnyi kodeks psykholoha [Ethical standards of psychologists] (2004). Psykholoh - A psychologist, 43 (139), 1-4 [in Ukrainian].

Zatvorniuk, O. M. (2010). Formuvannia u maibutnikh psykholohiv hotovnosti do profesiinoho samovdoskonalennia [Forming of future psychologists' readiness for professional self-improvement]. Candidate's thesis. Kyiv : Nats. ped. un-t im. M. P. Drahomanova [in Ukrainian].

Maralov, V.G., Voronina, O.A., \& Kisileva, E.P. (2011). Student kak subiekt samorazvitiia $i$ otnosheniia $k$ uchebno-professionalnoi deiatelnosti [Student as a subject of self-development and attitude to educational and professional activities]. V.G. Maralov (Ed.). Moskva: Academicheskii proekt; Mir [in Russian].

Minenko, O. O. (2004). Osobystisne zminiuvannia v protsesi profesiinoi pidhotovky studentiv-psykholohiv [Personality changing in the process of professional training of psychology students]. Extended abstract of candidate's thesis. Kyiv : Nats. ped. un-t im. M. P. Drahomanova [in Ukrainian].

Poplavska, M. V. (2014). Formuvannia hotovnosti maibutnikh inzheneriv do profesiino-osobystisnoho samorozvytku [Formation of future engineers' readiness for professional and personal self-development]. Extended abstract of candidate's thesis. Kharkiv : Ukr. inzh.-ped. akad. [in Ukrainian].

(C) Ketler-Mytnytska Tetiana

DOI (article): https://doi.org/10.32626/2227-6246.2019-46.199-218 http://journals.uran.ua/index.php/2227-6246 
Standart vyshchoi osvity Ukrainy $z$ haluzi znan 05 «Sotsialni ta povedinkovi nauky», spetsialnosti 053 "Psykholohiia», dlia pershoho (bakalavrskoho) rivnia osvity. Vydannia ofitsiine [Higher education standard of Ukraine in the field of knowledge 05 "Social and behavioral sciences», specialty 053 "Psychology", for the first (bachelor) level of education. The official publication ] (2019). Kyiv : Ministerstvo osvity i nauky Ukrainy [in Ukrainian].

Tereshchenko, L. A. (2017). Formuvannia prahnennia do samorozvytku u studentiv-psykholohiv yak faktora zapobihannia nevrotychnykh rozladiv yikhnoi osobystosti [Forming of striving for self-development of psychology students as a factor of preventing neurotic disorders of their personality]. S. D. Maksymenko (Ed.). Diialnisna samorealizatsiia osobystosti $v$ osvitnomu prostori - Active self-realization of personality in the educational space (pp. 208-224). Kyiv : Vydavnychyi dim «Slovo» [in Ukrainian].

Falko, N. M. (2009). Psykholohichnyi suprovid studentiv VNZ psykholohopedahohichnykh spetsialnostei $\mathrm{z}$ metoiu formuvannia yikh internalnykh yakostei [Psychological support of students of higher educational institutions of psychological and pedagogical specialties in order to form their internal qualities]. S. D. Maksymenko, L. A. Onufriieva (Ed.). Zbirnyk naukovykh prats Kamianets-Podilskoho natsionalnoho universytetu imeni Ivana Ohiienka, Instytutu psykholohii im. H. S. Kostiuka APN Ukrainy - Collection of research papers of Kamianets-Podilskyi National University named after Ivan Ohiienko, G. S. Kostiuk Institute of Psychology of NAPS of Ukraine, 6, 2, 312323. Kamianets-Podilskyi : Aksioma [in Ukrainian].

Frytsiuk, V. A. (2016). Sutnisni kharakterystyky hotovnosti maibutnikh fakhivtsiv do profesiinoho samorozvytku [Essential characteristics of future specialists' readiness for professional self-development]. Problemy inzhenerno-pedahohichnoi osvity - Problems of engineering and pedagogical education, 50-51, 374-384 [in Ukrainian].

Chorna, N. B. (2016). Formuvannia hotovnosti do profesiinoho samorozvytku maibutnikh uchyteliv mystetskykh spetsialnostei [Forming of readiness for professional self-development of future teachers of art specialties]. Candidate's thesis. Vinnytsia : Vinnytskyi derzh. ped. un-t imeni Mykhaila Kotsiubynskoho [in Ukrainian].

Chursina, A.S. (2011). Formirovanie gotovnosti k professionalnomu samorazvitiiu u studentov vuza $\mathrm{v}$ protsesse izucheniia psikhologo-pedagogicheskikh distsiplin [Forming of readiness for professional selfdevelopment of university students in the process of studying psychological and pedagogical disciplines]. Candidate's thesis. Cheliabinsk: Cheliabinskii gos. un-t [in Russian].

(C) Ketler-Mytnytska Tetiana

DOI (article): https://doi.org/10.32626/2227-6246.2019-46.199-218 
DOI: https://doi.org/10.32626/2227-6246.2019-46

Rotter, J. B. (1966). Generalized expectances for internal versus external control of reinforcement. Psychol. Monogr., 80, 1, 11-28.

Rotter, J. B. (1982). The development and applications of social learning theory: Selected papers. New York : Praeger.

Zawawi, J. A., \& Hamaideh, S. H. (2009). Depressive Symptoms and Their Correlates with Locus of Control and Satisfaction with Life among Jordanian College Students. Europe's Journal of Psychology, 4, 71-103.

Кетлер-Митницька Тетяна. Зміст і результати впровадження програми формування інтернальності як чинника готовності майбутніх психологів до особистісно-професійного саморозвитку

\section{АНОТАЦІЯ}

Метою статmі є опис змісту й аналіз результатів упровадження програми формування інтернальності як чинника готовності майбутніх психологів до особистісно-професійного саморозвитку. В статті розглянуто актуальність проблеми формування інтернальності майбутніх психологів у контексті професійних вимог. Наведено дані експериментальних досліджень щодо формування інтернальності майбутніх психологів і готовності до особистісно-професійного саморозвитку. Встановлено, що у здійснених дослідженнях не розкрито природу взаємозв'язку між цими властивостями та не запропоновано засобів формування інтернальності як чинника здатності до саморозвитку.

Представлено авторську модель, що описує систему формування інтернальності як чинника готовності майбутніх психологів до особистісно-професійного саморозвитку. Модель передбачає впровадження програми формування інтернальності, що включає навчальний курс, психологічний тренінг і засідання дискусійного клубу. Розкрито зміст, форми та методи запропонованих напрямків роботи. Метою програми $\epsilon$ розвиток когнітивного, особистісного та регуляторного компонентів інтернальності майбутніх психологів. Своєю чергою, їх формування спрямовано на стимулювання когнітивного, аксіологічно-мотиваційного та поведінкового компонентів готовності до особистісно-професійного саморозвитку. Надано інформачію про навчальні заклади та кількість майбутніх психологів четвертого та п'ятого курсів, які брали участь у формувальному експерименті. Представлено психодіагностичні методики, використані для порівняння рівнів сформованості кожного компонента до та після експерименту.

(C) Ketler-Mytnytska Tetiana

DOI (article): https://doi.org/10.32626/2227-6246.2019-46.199-218 http://journals.uran.ua/index.php/2227-6246 
DOI: https://doi.org/10.32626/2227-6246.2019-46 2019. Випуск 46

За допомогою факторного аналізу виявлено фактори інтернальності майбутніх психологів як чинника готовності до особистісно-професійного саморозвитку. Порівняно рівні сформованості кожного фактора до та після впровадження програми. Аналіз підтвердив статистично значущу позитивну динаміку розвитку означених факторів.

Отже, результати формуючого експерименту дають підстави стверджувати, що авторська програма формування інтернальності $\epsilon$ ерективною, а їі впровадження у практику вищої освіти допоможе стимулювати особистісно-профресійний саморозвиток майбутніх психологів.

Ключові слова: інтернальність, готовність до особистісно-професійного саморозвитку, модель формування інтернальності, формувальний експеримент, фактори.

Кетлер-Митницкая Татьяна. Содержание и результаты внедрения программы формирования интернальности как фактора готовности будущих психологов к личностно-профессиональному саморазвитию

\section{АННОТАЦИЯ}

Целью статьи является описание содержания и анализ результатов внедрения программы формирования интернальности как фактора готовности будущих психологов кличностно-профрессиональному саморазвитию. В статье рассмотрена актуальность проблемы формирования интернальности будущих психологов в контексте профрессиональных требований. Приведены данные экспериментальных исследований по формированию интернальности и готовности к личностно-профессиональному саморазвитию будущих психологов. Установлено, что в проведенных исследованиях не раскрыта природа взаимосвязи между этими свойствами и не предложены средства формирования интернальности как фактора способности к саморазвитию.

Представлена авторская модель системы формирования интернальности как фактора готовности будущих психологов к личностнопрофрессиональному саморазвитию. Модель предусматривает внедрение программы формирования интернальности, которая включает учебный курс, психологический тренинг и заседания дискуссионного клуба. Раскрыты содержание, формы и методы предложенных направлений работы. Целью программы является развитие когнитивного, личностного и регуляторного компонентов интернальности. В свою очередь,

(C) Ketler-Mytnytska Tetiana

DOI (article): https://doi.org/10.32626/2227-6246.2019-46.199-218 
DOI: https://doi.org/10.32626/2227-6246.2019-46

их формирование направлено на стимулирование когнитивного, аксиологически-мотивационного и поведенческого компонентов готовности к личностно-профессиональному саморазвитию. Предоставлена информация об учебных заведениях и количестве студентов четвертого и пятого курсов, которые участвовали в формирующем эксперименте. Названы психодиагностические методики, использованные для сравнения уровней сформированности каждого компонента до и после эксперимента.

С помощью факторного анализа выявлены факторы интернальности будущих психологов в контексте ее влияния на готовность к личностно-профессиональному саморазвитию. Сравнение уровней сформированности факторов до и после внедрения программы подтвердило статистически значимую положительную динамику их развития.

Таким образом, результаты формирующего эксперимента позволяют утверждать, что авторская программа формирования интернальности является эффрективной, а ее внедрение в практику высшего образования поможет стимулировать личностно-профессиональное саморазвитие будущих психологов.

Ключевые слова: интернальность, готовность к личностно-профессиональному саморазвитию, модель формирования интернальности, фрормирующий эксперимент, фракторы.

Original manuscript received September 24, 2019 Revised manuscript accepted October 19, 2019

(C) Ketler-Mytnytska Tetiana

DOI (article): https://doi.org/10.32626/2227-6246.2019-46.199-218 http://journals.uran.ua/index.php/2227-6246 